\title{
A MINERALOGICAL STUDY OF SOME MYCENAEAN SEALS EMPLOYING MOBILE RAMAN MICROSCOPY
}

\author{
Economou G. ${ }^{1}$, Kougemitrou I. ${ }^{1}$, Perraki M. ${ }^{2}$, Konstantinidi-Syvridi E. ${ }^{3}$ \\ and Smith D.C. ${ }^{4}$ \\ ${ }^{1}$ Institute of Geolical and. Mineralogical Exploration (IGME), Department of Mineralogy and Petrography, \\ c.entrance, Olympic village, 13677 Acharnai, Greece, dop@igme.gr \\ ${ }^{2}$ National Technical University of Athens, School of Mining and Metallurgical Engineering, \\ Division of Geological Sciences, 9 Heroon Politechniou Str., 15773 Zografou, \\ Athens,Greece,maria@metal.tua.gr \\ ${ }^{3}$ National Archaeological Museum, 1 Tositsa St., 10682, Athens, Greece, ekonstant09@gmail.com \\ ${ }^{4}$ Museum National d'Histoire Naturelle (LMCM, CNRS 7072, USM0205), 61 Rue Buffon, \\ 75005 Paris, France, davsmith@mnhn.fr
}

\begin{abstract}
The National Archaeological Museum in Athens is the largest archaeological museum in Greece, and one of the most important museums in the world, devoted to Ancient Greek art and history. Among other exhibits, it owns a large collection of gemstones some of which were used during prehistoric times (Mycenaean period) as seals. Their shape varies from round to oval, flattish or cylindrical, and they are delicately engraved as intaglios with a variety of depictions (lions, bulls, man, etc). They show a wide range of colours from reddish, brown, to purplish and blue. The six sealstones described here come from the Chamber Tombs of Mycenae (15 th $14^{\text {th }}$ cent. BC). Museum exhibit labels recognize them as varieties of quartz such as jasper (NAM 3138), sardonyx (NAM 2316 \& 2865), agate (NAM 4928), amazonite (NAM 2863) and gold-mounted carnelian (NAM 6489). Raman Spectroscopic analysis has been carried out with a new MRM (Mobile Raman Microscope) using a Kaiser Holoprobe with a NIR $785 \mathrm{~nm}$ laser. The Raman spectra acquired from $1 \mathrm{~s}$-60s measurements confirmed that, in all six sealstones, quartz was the major mineral species clearly identified by its characteristic peaks. The second most important phase was moganite, a little-known polymorph of quartz. The amber-coloured sealstone (NAM 6489) was confirmed as carnelian, whereas the blue-green amazonite-coloured sealstone (NAM 2863) was not detected as amazonite. Small amounts of haematite were detected in the NAM 2865 \& NAM 3138.
\end{abstract}

Key words: Mycenaean sealstones, gemstones, Raman spectroscopy, archaeometry.

\section{Introduction}

Raman spectroscopy has become an important technique in Archaeometric studies, in Archaeology and Art History since about 1996, due principally to its microscopical, no sample treatment and nondestructive capacities, and the pseudo-acronym 'ARCHAEORAMAN' was coined by Smith (1999) to summarize this wide field of research activity. 'Mobile Raman Microscopy' (MRM) was also employed (Smith, 1999, 2002) to analyze art works in situ, directly in the museums by taking the lab- 
oratory to the object, rather than taking the object to the laboratory as in conventional 'Immobile Raman Microscopy' (IRM). Apart from non-destructiveness MRM has gained ground among other physicochemical methods due to the small amount of sample required and the high spatial resolution allowing the analysis of small heterogeneities in complex matrix.

Textbook explanations of Raman Spectroscopy for Geologists, Gemmologists and Archaeologists are provided in Smith and Carabatos (2001) and Nasdala et al. (2004) and reviews on MRM applications in Gemmology are available in Smith $(2005,2006)$. A gemmological database for the Raman spectra of gems was published by Pinet et al. (1992).

In the early 2000's several other researchers in the UK (H.G.M.Edwards), Belgium (P.Vandenabeele), France (P. Colomban), Switzerland (L. Kiefert), Spain (F. Rull-Perez) and Italy (G. Di Lonardo), have helped to pioneer MRM in Archaeometry, and in the late 2000's this topic lead to an exponential increase in publications and frequent international congresses.

The National Archaeological Museum in Athens, owns a large collection of gemstones including some prehistoric seals $\left(15^{\text {th }}-14^{\text {th }}\right.$ cent. BC), from the Mycenaean Chamber Tombs. They came in the limelight after the excavations of 1892 . They are mostly round or oval, and flattish or cylindrical; altogether they show a very wide range of colours ranging from reddish and brown to purplish and blue. They are delicately engraved like intaglios and depict a large variety of themes from the everyday activity and the nature (Vasilikou, 1995). Whilst carrying out a new MRM (Mobile Raman Microscopy) analytical operation in the NAM on pigmented artworks using a Kaiser Holoprobe MRM from IGME (Athens) fitted with a NIR $785 \mathrm{~nm}$ laser and a specially-made strong tripod support, six sealstones were extracted from their glass display case to make some rapid non-destructive analyses of the material in an attempt to establish definitively the mineral species present in these carved stones, and, by consequence, also the rock type when possible.

\section{Art History and Seal engraving in Prehistoric Greece}

Seals were particularly important for the period in question (Late Bronze Age, 1500-1100 BC), as they were connected with trade and administration. The abundance of materials used and their iconography provides information for the everyday life and the religion of the Mycenaeans. Workshops for the manufacture of seals existed in the palace centers of Crete and the Peloponnese (Mycenae, Tiryns, Pylos), as they formed part of the administrative system. They were usually made of semi-precious stones (quartz, amethyst, agate, jasper, carnelian, haematite, rock-crystal), but also of artificial materials such as glass and faience or organic materials like bone and ivory; sometimes they were gold-mounted. The most popular shapes were the lentoid, the almond-shaped and the cylindrical. Apart from their use to protect the products to be transported from theft (by leaving their impression on wet clay placed on the mouth of storage objects), seals were also worn as jewellery, with protective or purely decorative character. To their owners, they constituted a symbol of prestige (Sakellariou, 1964; Vasilikou, 1995). Lions were a very popular theme for the seals as well as for other forms of Mycenaean art. They were a symbol of royal strength. The bull was another frequent theme as it was the dominant animal for sacrifice. The leaping bull used to be a kind of ceremony in social events. Well-trained male and female acrobats used to catch the bull from its horns and jump on to its back (Sakellariou, 1964; Vasilikou, 1995).

\section{Mineralogical considerations}

The very common mineral species quartz $\left(\alpha-\mathrm{SiO}_{2}\right)$ may occur as monocrystals. If there is no other 
mineral phase present the colour would be colourless or white (rock crystal) or may be coloured due to impurities, usually of $\mathrm{Fe}^{3+}$-rich minerals like rose quartz (pink colour), citrine (yellow), amethyst (purple), morion (black) etc. Yet other varieties may be coloured by intergrown extra mineral phases like green fuchsite (aventurine), blue dumortierite or zoisite, brown riebeckite (crocidolite), haematite, gold or cupreous rutile (rutilized quartz). Quartz of invisible microcrystalline size is called cryptocrystalline quartz. The main colour of those varieties can be defined by the combination of texture and features. Some varieties are chalcedony, agate, sard, onyx, sardonyx, jasper, carnelian, prase, chrysoprase, heliotrope. Usually the quartz is accompanied by the polymorph moganite $\left(\mathrm{SiO}_{2}\right)$ that was discovered only recently, having a crystal structure that resembles $\alpha$-quartz twinned on a unit cell scale. It is still not known why this moganite exists; probably it is related to the kinetics and chemistry of percolating solutions during growth).

All varieties of cryptocrystalline quartz show the same essential physical and chemical properties as $\alpha$-quartz, with additional moganite in variable proportions (Table 1).

Table 1. Physical properties of quartz and cryptocrystalline quartz varieties.

\begin{tabular}{|c|l|c|l|}
\hline Mineral Class & Oxides & Mineral Species & Quartz (alpha) \\
\hline Chemical Composition & $\mathrm{SiO} 2$ & Crystal system & Trigonal \\
\hline Hardness & 7 & Specific Gravity & 2,66 \\
\hline Refractive Index & $1,544-1,533$ & Appearance & Vitreous, opaque \\
\hline Cleavage & Poor & Fracture & Conchoidal \\
\hline
\end{tabular}

\section{Etymology and use in ancient Greece}

Gemological notes on the colours, etymology and uses in antiquity (Cipriani and Borelli, 1986; Harding, 2007) for the mentioned chalcedonies are provided below:

Agate

Colour: No gemstone is more creatively striped by Nature than agate that forms in concentric layers in a wide variety of colours and textures. Each individual agate forms by filling a cavity/vesicle in the host rock. As a result, agate is often found as a rounded nodule, with very fine concentric bands like the rings of a tree trunk. The bands sometimes look like eyes, sometimes-fanciful scallops, or even a landscape with dendritic trees.

Etymology: The name originates from the word "Achates", the ancient Greek name of the Sicilian river Drillo in which the mineral was first found. Agate was highly valued as an amulet in ancient times. It was said to quench thirst and protect from fevers.

Sardonyx

Colour: Reddish-brown with prominent white strips and bands. 
Etymology: The name sardonyx derives from the words "sard", and "onyx" related to the striped or banded appearance of layers of white, grey or black interspersed with reddish-brown. According to Pliny, sard is named after "Sardis" where the mentioned mineral is found. The ancient Greeks and the Romans were very fond of sardonyx and believed it could bring courage and victory.

\section{Carnelian}

Colour: Reddish-orange or brownish-orange due to the traces of the ferric iron oxide haematite $\left(\mathrm{Fe}_{2} \mathrm{O}_{3}\right)$.

Etymology: The name carnelian is said to be derived from the Latin word "carnis", meaning "flesh", due to its colour. Others believe that the name comes from a variety of cherry having the same colour. This gemstone is believed to cleanse the blood and improve one's outlook too. It had been believed for a long time that the carnelian gemstone stops bleeding and helps heal wounds.

\section{Jasper}

Colour: Commonly red, it also comes in pink, yellow, green, brown, black, and greyish blues and frequently in combinations of these colours. The association with other minerals gives jasper nice bands and patterns.

Etymology: The Greek origin of the word jasper, "iaspis", means "spotted stone". The black variety known as "Lydia lithos" (=stone of Lydia) was used for thousands of years for the quantification of gold in various alloys. The test is done by friction of the sample on the jasper. The colour of the dust line produced is used to calculate the quantity of pure gold in the alloy. The gem was a favourite in the ancient world, and the name jasper can be traced back in Hebrew, Assyrian, Persian, Greek and Latin. People of the 4th century (BC) used to call it the great "rain-bringer",» and it has been considered to strengthen the stomach and cure gynaecological troubles. Some people also used it to drive away evil spirits and protect against snake and spider bites. It supposedly gives you the courage to speak out and the bravery to achieve personal independence.

\section{Materials and Methods}

Six sealstones from the large gemstone collection of the National Archaeological Museum in Athens, were studied by means of portable Raman microscopy. The sealstones studied here are depicted in Fig. 1 and detailed described in Table 2. They come from the Chamber Tombs of Mycenae (mainly $14^{\text {th }}-13^{\text {th }}$ century BC), family tombs of both high-ranking officials and simple civilians, around the Mycenaean citadel (Vasilikou, 1995). They are mostly round or oval, and flattish or cylindrical, and are delicately engraved like intaglios; altogether they show a very wide range of colours ranging from reddish and brown to purplish and blue. Color inhomogeneities occur in the sealstone No 2316.

A Kaiser "Holoprobe" Mobile Raman Microscope (MRM) from the Institute of Geological and Mineral Exploration (IGME) of Athens, Greece, was tested for the first time directly in the National Archaeological Museum (NAM) of Athens, Greece. The analysis was carried out using a $785 \mathrm{~nm}$ laser. A calibration of the instrument was obtained with a standard of Si, giving a characteristic peak at the $520.5 \mathrm{~cm}^{-1}$. Preparation of the samples was not necessary and the samples were placed in front of the focused $785 \mathrm{~nm}$ laser in their normal form. The video camera of the Raman system was employed in order to be able to observe different areas of the sealstones. The power of the laser was $200-500 \mathrm{~mW}$. The Raman spectra were acquired from 1-6 s and 1-10 accumulations and they were treated with HoloGRAMS 4.0 software (baseline correction, peak fit). 


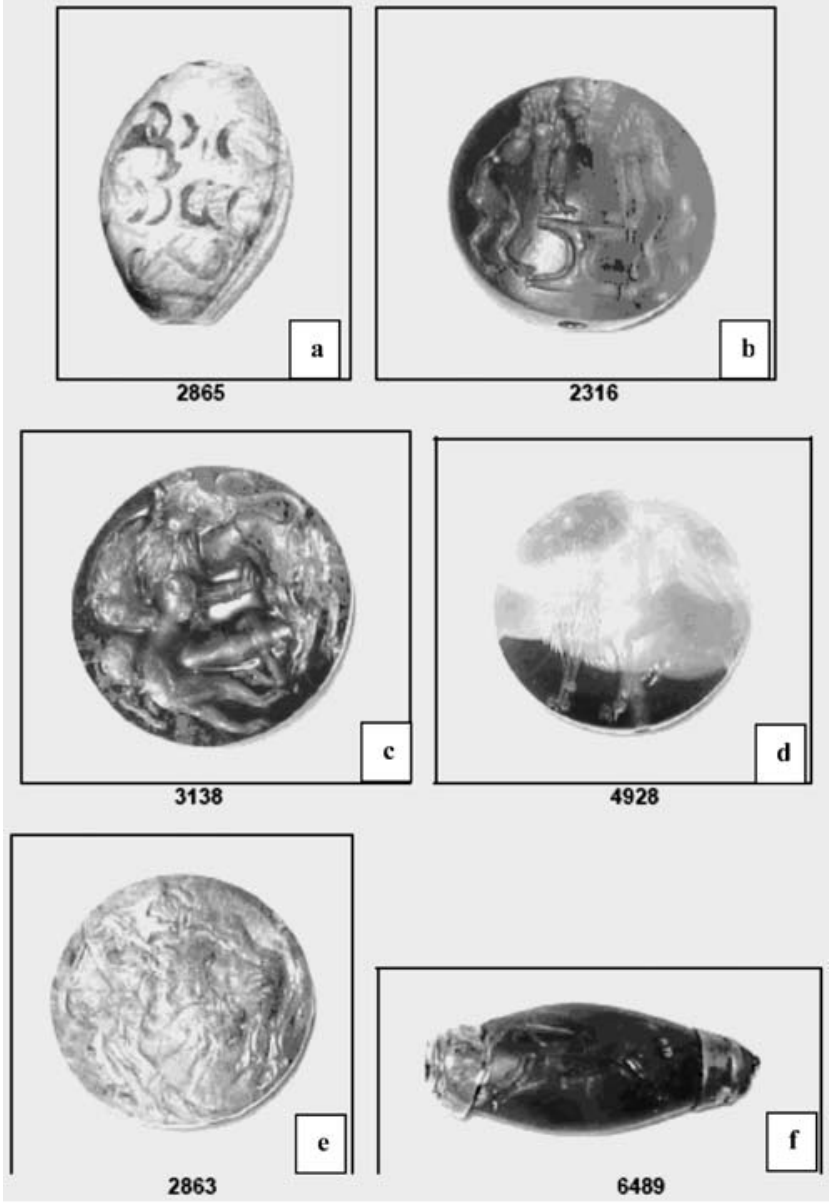

Fig. 1: Photographs displaying the shape, colour and engraved patterns of the six sealstones examined, a: a sea plant engraved on sardonyx, $b$ : two heraldic lions engraved on sardonyx, c: two lions attacking a bull engraved on jasper, $\mathrm{d}$ : a man fighting a lion engraved on agate, e: a man capturing two bulls engraved on amazonite, f: a bull leaping engraved on carnelian.

\section{Results and Discussion}

The spectra acquired during the analysis of the Mycenean seals, confirmed the exhibit labels for the majority of the cases considered herein. Representative Raman spectra of the sealstones analyzed here are given in Fig. 2.

The comparison of each spectrum with published fingerprint spectra (e.g. Kingma \& Hemley, 1994; Götze et al., 1998, Burgio \& Clark, 2001) revealed the presence of the mineral species summarised below:

Specimen 4928: $\alpha$-quartz and moganite were detected by their characteristic bands respectively at 464 and $502 \mathrm{~cm}^{-1}$ Moganite is known to coexist with a-quartz in many types of chalcedony such that most of these sealstones were confirmed, -, as chalcedony, but of different varieties according to their colours and textures (e.g. agate, jasper, sardonyx). However the proportion of moganite varied from very poor to very rich with $\mathrm{I}_{502} / \mathrm{I}_{465}=\sim 35 \%$ in NAM 4928. The proportion of moganite is a key crystallographical/petrographical feature that may help to locate the geological provenances of these stones (Kingma \& Hemley, 1994; Götze et al., 1998).

Specimen 2316: Only the yellow part of the sealstone was analysed in the time available. Quartz 
Table 2. Description of the sealstones.

\begin{tabular}{|c|c|c|c|c|c|c|}
\hline $\begin{array}{l}\text { Specimen } \\
\text { Code }\end{array}$ & $\begin{array}{l}\text { Museum } \\
\text { label }\end{array}$ & Color & Shape & $\begin{array}{c}\text { Diameter } \\
(\mathrm{cm})\end{array}$ & Shematic & $\begin{array}{c}\text { Chamber } \\
\text { tomb }\end{array}$ \\
\hline $\begin{array}{l}2865 \\
\text { (Sakellariou-Xe- } \\
\text { naki, 1985) }\end{array}$ & Sardonyx & Pink-white & $\begin{array}{l}\text { Almond- } \\
\text { shaped }\end{array}$ & $1.6-2.2$ & Sea plant & \\
\hline $\begin{array}{l}2316 \\
\text { (Sakellariou, } \\
\text { 1964; Sakellariou- } \\
\text { Xenaki, 1985) }\end{array}$ & Sardonyx & Red-yellow & Lentoid & 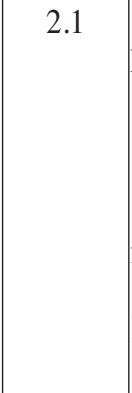 & $\begin{array}{c}\text { Two heraldic lions } \\
\text { have their front legs up } \\
\text { and step onto an altar. } \\
\text { Bodies are rendered in } \\
\text { katatomi, while their } \\
\text { common head in } \\
\text { frontal view.The repre- } \\
\text { sentation recalls the } \\
\text { large of the Lions Gate } \\
\text { at Mycenae. }\end{array}$ & 8 \\
\hline $\begin{array}{l}3138 \\
\text { (Sakellariou, } \\
\text { 1964; Sakellariou- } \\
\text { Xenaki, 1985) }\end{array}$ & Jasper & Red-brown & Lentoid & $2.5-2.6$ & $\begin{array}{l}\text { Two lions attacking a } \\
\text { bull. The two lions are } \\
\text { fighting over the bull } \\
\text { and bite each other on } \\
\text { the back. }\end{array}$ & 83 \\
\hline $\begin{array}{l}4928 \\
\text { (Sakellariou, } \\
\text { 1964; Sakellariou- } \\
\text { Xenaki, 1985) }\end{array}$ & Agate & $\begin{array}{l}\text { Purplish } \\
\text { gray-brown }\end{array}$ & Lentoid & 2.75 & $\begin{array}{l}\text { A man fighting a } \\
\text { lion }\end{array}$ & 103 \\
\hline $\begin{array}{l}2863 \\
\text { (Sakellariou, } \\
\text { 1964; Sakellariou- } \\
\text { Xenaki, 1985) }\end{array}$ & $\begin{array}{l}\text { Ama- } \\
\text { zonite }\end{array}$ & Blue-gray & Lendoid & 2.2 & $\begin{array}{l}\text { A man captures a } \\
\text { bull from the head } \\
\text { and one of the legs. }\end{array}$ & 58 \\
\hline $\begin{array}{l}6489 \\
\text { (Wace, 1932; } \\
\text { Sakellariou, 1964) }\end{array}$ & Carnelian & Amber-gold & $\begin{array}{l}\text { Almond- } \\
\text { shaped }\end{array}$ & $1-2.7$ & Bull leaping & 518 \\
\hline
\end{tabular}

$\left(206,354,464 \mathrm{~cm}^{-1}\right)$ was found and a weak band at $397 \mathrm{~cm}^{-1}$ could indicate the presence of goethite, which is a typical yellow $\mathrm{Fe}^{+3}$ colorant (Burgio \& Clark, 2001).

Specimen 6489: Quartz and moganite are present, as indicated by the dominant bands at 464 and $502 \mathrm{~cm}^{-1}$.

Specimen 3138: Quartz and possibly moganite occur with their characteristic bands at 465 and 501 (very weak) $\mathrm{cm}^{-1}$, respectively. Also the presence of haematite $\left(224,411,612 \mathrm{~cm}^{-1}\right)$ and indications of goethite $\left(293,387,393 \mathrm{~cm}^{-1}\right)$ were observed.

Specimen 2863: Quartz, possibly moganite and a copper mineral in question, judging and from the 


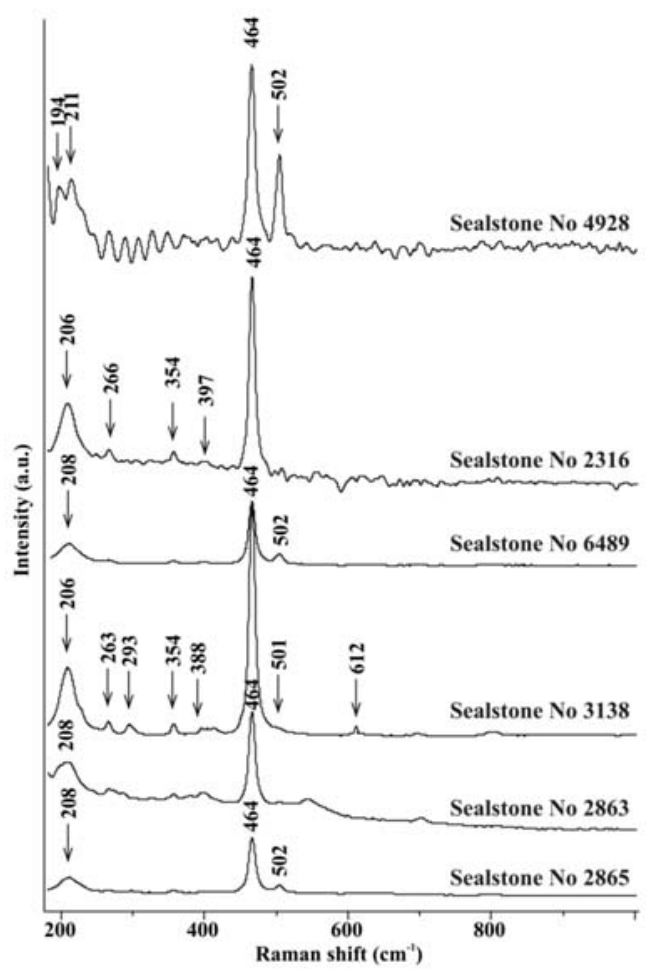

Fig. 2: Raman spectra of the six sealstones analysed; 4928: admixture of a-quartz and moganite, 2316: quartz and goethite, 6489: admixture of a-quartz and moganite, 3138: admixtrure of a-quartz and moganite with presence of haematite and goethite, 2863: aquartz, 2865: admixture of a-quartz and moganite with presence of haematite.

colour of the stone. More analytical time is necessary to search for the additional bands.

Specimen 2865: Quartz $\left(464 \mathrm{~cm}^{-1}\right)$ and moganite $\left(502 \mathrm{~cm}^{-1}\right)$ exist. Haematite is indicated by a weak band at $411 \mathrm{~cm}^{-1}$. More analytical time is necessary to clarify the nature of the extra bands.

\section{Conclusions}

The Raman spectra acquired rapidly from a few 1s - 60s measurements confirmed that, in all six sealstones, quartz was the major mineral species clearly identified by its characteristic peaks; (major Raman peak at $\left.465 \mathrm{~cm}^{-1}\right)$; nevertheless it was never found alone. The second most important phase found was moganite, the little-known polymorph of quartz with its strongest peak at $502 \mathrm{~cm}^{-1}$. The amber-coloured sealstone NAM 6489 is compatible with carnelian, but no proof of the presence of an iron oxide colouring agent was detected. The blue-green coloured sealstone NAM 2863, previously recognized as amazonite by the archaologists, did not reveal any trace of microcline feldspar - through its Raman analysis; on the contrary, it revealed quartz and moganite; it might be an agate coloured blue by precipitated copper minerals. Thus one of the assignments claimed by the Museum labels is vitiated.

Small amounts of haematite $\left\{\mathrm{Fe}_{2} \mathrm{O}_{3}\right\}$ were also detected in two samples (NAM 2865 \& NAM 3138) and the presence of goethite $\{\mathrm{FeOOH}\}$ is indicated in two samples (NAM 2316 \& NAM 3138). These are to be expected in minerals coloured respectively red or yellow by iron.

Four of these six sealstones revealed some extra Raman bands that have not yet been attributed and merit further Raman analyses to help elucidate non-destructively the nature of the extra mineral species present. The species of these extra mineral phases should help to better determine the petrogenesis of these rocks and also be a valuable aid to studying their provenance. 


\section{Acknowledgments}

The authors would like to acknowledge Dr. Nikolaos Kaltsas, the Director of the National Archaeological Museum of Athens. The personnel of the Museum kindly helped during the various stages of this project. Constructive review comments from an anonymous reviewer are highle appreciated.

\section{References}

Burgio, L., Clark, R.J.H., 2001. Library of FT-Raan spectra of pigments, minerals, pigment media and varnishes, and supplement to existing library of Raman spectra of pigments with visible excitation. Spectrochimica Acta part A 57, 1491-1521.

Cipriani, C., Borelli, A., 1986. Simon \& Schuster's guide to gems and precious stones. Simon \& Schuster Inc., 384pp.

Götze, J., Nasdala, L., Kleeberg, L., and Wenzel, M., 1998. Occurence and distribution of "moganite" in agate/chalcedony: a combined microRaman, Rietvelt and cathodoluminescence study, Contribution to Mineralogy and Petrology 133, 96-105.

Harding, J., 2007. Crystals. F \& W Pubns Inc, 320 pp.

Kingma, K.J., Hemley, R.J. 1994. Raman spectroscopic study of microcrystalline silica. American Mineralogist 79, 269-273.

Nasdala L., Smith, D.C., Kaindl, R. \& Ziemann, M.A. 2004. Raman Spectroscopy: Analytical perspectives in mineralogical research. In: Beran, A., Libowitzky, E. (Eds.), EMU Notes in Mineralogy, EMU School on Spectroscopic Methods in Mineralogy 7, 281-343.

Pinet, M., Smith, D.C. \& Lasnier, B. 1992. Utilité de la microsonde Raman pour l'identification nondestructive des gemmes, avec une sélection représentative de leurs spectres Raman. In : Schubnel, H.J., Smith, D.C. (Eds.) La Microsonde Raman en Gemmologie, Revue de Gemmologie, n spécial hors série 1992, Assoc. Française Gemmologie, ch. II, 11-61.

Sakellariou, A. 1964. Corpus der Minoischen und Mykenischen Siegel, Band 1; Die Minoischen und Mykenischen Siegel des National Museums in Athen.

Sakellariou - Xenaki, A. Oi Thalamatoi tafoi ton Mykinon. Anaskafis Xr. Tsounta. Paris 1985, p. 223.

Smith, D.C. 1999. Invited «Feature article», Mineralogical Society Bulletin, 3-8.

Smith, D.C. \& Carabatos-Nedelec, C. 2001. Raman Spectroscopy Applied to Crystals: Phenomena and Principles, Concepts and Conventions. In: LEWIS, I. and EDWARDS, H.G.M. (Eds), A Handbook on Raman Spectroscopy, Marcel Dekker Inc., 9, 349-422.

Smith, D.C., 2002. Archaeoraman and Mobile Raman Microscopy (MRM): from pigments in aerial wallpaintings to gemstones in submarine archaeometry, Congress Georaman, Acta Universitatis Carolinae, Geologica, Praha, 46/1, 84-86.

Smith, D.C., 2005. Jewellery and precious stones, Raman Spectrometry in Archaeology and Art History, The Royal Society of Chemistry, London, ch. 21, 335-378.

Smith, D.C., 2006. A review of the non-destructive identification of diverse geomaterials in the Cultural Heritage using different configurations of Raman Spectroscopy. In: Maggetti, M. \& Messiga, B. (Eds). Invited paper, ch. 2, 9-32. Proceedings, 32nd International Geological Congress, Florence, August 2004, «Geomaterials in Cultural Heritage», Spec. Pub. 257, Geol. Soc. London.

Vasilikou, D., 1995. The Mycenaean Civilisation, Athens.

Wace, A.J.B., 1932. Chamber Tombs at Mycenae, Archaeologia 82, p. 182. 